\title{
Growth and Yield of Reishi Mushroom [Ganoderma lucidum (Curtis) P. Karst] in Different Sawdust Substrates
}

\author{
L.A.M.N. Jeewanthi ${ }^{1, *}$, K. Ratnayake ${ }^{1}$ and P. Rajapakse ${ }^{2}$
}

\begin{abstract}
Ganoderma lucidum (Reishi mushroom) is a medicinal mushroom which possesses numerous health benefits. With a view to popularize the cultivation of G. lucidum in Sri Lanka, a study was done to identify an appropriate substrate from local raw materials for its artificial cultivation in polypropylene bags. Sawdust of four woods viz. Rubber (Hevea brasiliensis), Mango (Mangifera indica), Jack (Artocarpus heterophyllus) and Lunumidella (Melia dubia) were used as substrates after mixing with other general ingredients. The mushroom was grown in $100 \%$ Rubber, $100 \%$ Mango, 100\% Jack, $100 \%$ Lunumidella, $50 \%$ Rubber $+\mathbf{5 0 \%}$ Mango, 50\% Rubber + 50\% Jack, and 50\% Rubber $+50 \%$ Lunumidella sawdust combinations. The number of days taken for colonization and primordial formation, number of fruiting bodies per bag, yield per bag and Biological Efficiency (BE) were recorded. Substrates with Mango (100\%), Rubber (100\%), Rubber + Mango (50\%:50\%) and Rubber + Lunumidella (50\%:50\%) sawdust resulted in equally high yield per bag (49.3 g, $42.5 \mathrm{~g}, 45.7 \mathrm{~g}$ and $43.7 \mathrm{~g}$, respectively) within 1 month after primordia formation, and higher $\mathrm{BE}$ of $5.4 \%, 5.1 \%, 5.3 \%$ and $5.7 \%$,
\end{abstract}

\footnotetext{
${ }^{1}$ Department of Horticulture and Landscape Gardening, Faculty of Agriculture and Plantation Management, Wayamba University of Sri Lanka, Makandura, Gonawila (NWP), 60170, Sri Lanka ${ }^{2}$ Regional Agricultural Research and Development Centre, Makandura, Gonawila, 60170, Sri Lanka *nisansalajeewanthi123@gmail.com
}

respectively. Higher predicted total yields for a duration of 3 months were resulted by $100 \%$ Mango sawdust (541.91 g/bag), Rubber + Mango sawdust (502.37 g/bag), and Rubber + Lunumidella sawdust $(480.92 \mathrm{~g} / \mathrm{bag})$, followed by Rubber $(467.39 \mathrm{~g} / \mathrm{bag})$ substrates while the minimum yield $(289.08 \mathrm{~g} / \mathrm{bag})$ was given by Rubber + Jack sawdust mixture. Considering the scarcity of rubber and mango wood as a sole source for substrate, the mixture of rubber and mango $(50 \%: 50 \%)$ or rubber and Lunumidella (50\%:50\%) could be successfully used for cultivation of $G$. lucidum.

Keywords: Biological efficiency, Ganoderma lucidum, Medicinal mushroom, Sawdust, Substrate

\section{INTRODUCTION}

A mushroom is a macro fungus with a distinctive fruiting body. They grow saprophytically or parasitically on dead organic matter (Chang and Miles, 1997). Mushrooms not only provide a nutritious, protein rich food, but also some species produce medicinally effective compounds (Chang and Miles, 2004).

Ganoderma lucidum has been recognized as a medicinal mushroom for over 4000 years in Far East countries and its powerful effects have been documented in ancient scripts (Wasser, 2005). It is a wood- 
decaying fungus and it causes white rot of a wide variety of trees (Chang and Miles, 2004). Ganoderma. lucidum is a large, dark and sculptured mushroom with a varnish appearance and woody texture. The fruiting bodies have a yellow to reddish laccate cuticle and an upper layer that is smooth or often concentrically zoned and grooved. Surface of the fruiting body is sometimes covered with brownish spore powder. In China, G. lucidum is called Ling zhi, and the Japanese name for Ganodermataceae family is Reishi (Wachtel-Galor et al., 2011). It contains various pharmacologically active compounds, including over 119 different triterpenes and several types of polysaccharides (Hsieh and Yang, 2004). The specific health benefits of Reishi mushroom include anti-tumor, anti-inflammatory, antimicrobial, hepato-protective, hypotensive, anti-diabetic, antioxidant, modulation of the immune system and bacteriostasis. Powders, dietary supplements, concentrated tablets, syrup and tea are commercial herbal products derived from G. lucidum (Wachtel-Galor et al., 2011).

Attempts have been made to cultivate $G$. lucidum artificially in the world, because of its irregular distribution in the wild and the rising demand for it as a medicinal product. Bottle procedure, sawdust bags, short wood segments, tree stumps and wood logs are the most widely used artificial cultivation methods of G. lucidum (Chang and Buswell, 1999).
Medicinal mushrooms are relatively new to Sri Lanka. Nevertheless, a potential exists to produce a variety of herbal products in household or industrial levels to popularize the consumption of Reishi mushroom among the general public.

With a view to developing an appropriate growing medium for commercial cultivation, the present study assessed the efficacy of sawdust substrates derived from four tree species commonly grown in Sri Lanka on growth and yield of G. lucidum.

\section{MATERIALS AND METHODS Experimental Site}

The study was conducted at the Regional Agricultural Research and Development Centre (RARDC), Makandura, Sri Lanka, located in the Low country Intermediate Zone (IL $1 \mathrm{a}$ ), at $25 \mathrm{~m}$ from mean sea level, in 2017. Mushroom spawns were provided by RARDC.

\section{Treatments and Mushroom Grow Bag Preparation}

Four different sawdust types namely Rubber (Hevea brasiliensis), Mango (Mangifera indica), Jack (Artocarpus heterophyllus) and Lunumidella (Melia dubia) were used as treatments when preparing the mushroom growbag mixture, while keeping the proportions of other ingredients constant (Table 1). 
Raw materials used (for 55 grow bags) were dried sawdust $(20 \mathrm{~kg})$, raw rice bran $(2$ $\mathrm{kg}$ ), dolomite (500 g), gypsum (200 g) and $\mathrm{MgSO}_{4}(50 \mathrm{~g})$. Moisture level of the mixture was adjusted to $65 \%$ (wet basis). Polypropylene (gauge 200) bags of $35 \mathrm{~cm}$ length and $17.5 \mathrm{~cm}$ width were tightly filled with the mixture, leaving $7-10 \mathrm{~cm}$ from the top of the bag. Neck of the bag was prepared using a $2 \mathrm{~cm}$ long piece of heat resistant PVC tube and the neck was plugged with cotton, covered with a piece of paper and tied with a rubber band.

Table 1. Sawdust types and their proportions used in the study.

\begin{tabular}{llc}
\hline Trt & \multicolumn{1}{c}{ Sawdust type } & $\begin{array}{c}\text { Percentage } \\
(\boldsymbol{\%})\end{array}$ \\
\hline T1 & Rubber & 100 \\
T2 & Mango & 100 \\
T3 & Jack & 100 \\
T4 & Lunumidella & 100 \\
T5 & Rubber: Mango & $50: 50$ \\
T6 & Rubber: Jack & $50: 50$ \\
T7 & Rubber: Lunumidella & $50: 50$ \\
\hline
\end{tabular}

The bags with media were sterilized using a boiler for $1.5 \mathrm{~h}$ at $115^{\circ} \mathrm{C}$ and $1.5 \times 10^{5}$ Pa pressure. Sterilized bags were transferred to an aseptic inoculation room and were allowed to cool for $24 \mathrm{~h}$.

\section{Incubation and Growth of Mushroom}

Mushroom spawns of G. lucidum were placed aseptically in the neck area of grow bags followed by covering. For incubation, the bags were kept vertically at room temperature $\left(28{ }^{\circ} \mathrm{C}\right.$ ) in the dark (Figure 1). When mycelium had fully colonized the substrate, bags were opened and transferred to the growth room at room temperature $\left(28{ }^{\circ} \mathrm{C}\right)$ and $85-90 \%$ relative humidity for the formation of fruiting bodies (Figure 1). Fruiting bodies were harvested when the caps became completely red and the white margin had disappeared.

\section{Data Recording and Statistical Analysis}

The number of days taken for spawn running (colonization period), pinhead formation, fruiting body maturity and first harvest were recorded. Number of fruiting bodies per bag and yield per bag ( $\mathrm{g}$ ) were also recorded. The yield parameters were recorded for a period of 1 month after fruiting body initiation.

Biological Efficiency (BE) percentage was calculated using the following equation (Roy et al., 2015).

$$
B E \%=\frac{\text { Total biological yield }(\mathrm{g})}{\text { Total dry substrate used }(\mathrm{g})} \times 100
$$

The experiment was arranged in a Completely Randomized Design (CRD) with three replicates and each replicate consisted of 20 grow bags. Five grow bags in each replicate were used for data recording. Data were analyzed using the Analysis of Variance (ANOVA) and group means were compared by Tukey's test using the Statistical Analysis 
System SAS software (Version 9.4).

\section{RESULTS AND DISCUSSION}

\section{Effect of Sawdust Type on Mushroom Colonization Period}

The growth and yield parameters of $G$. lucidum under various sawdust substrates are presented in Table 2. More vigorous and the fastest colonization period was observed in $100 \%$ Rubber (25.4 d) and Rubber + Lunumidella (50\%:50\%; 25.6 d) sawdust substrates. Jack sawdust $(100 \%)$ showed a significantly $(\mathrm{p}<0.05)$ slow rate $(34.2 \mathrm{~d})$ of mycelial growth in relation to other sawdust types. The mycelial growth completed within 28 days for all treatments except for $100 \%$ Jack sawdust (Figure 2). These results are consistent with the results reported by Bandaranayake et al. (2012) where a faster colonization of G. lucidum was achieved in $100 \%$ Rubber (27 d) and 100\% Lunumidella (23 d) sawdust.

In Bangladesh, a colonization period of 9 days and 6 days was reported for Swietenia mahagoni sawdust supplemented with rice bran and wheat bran, respectively for artificial cultivation of G. lucidum (Roy et al., 2015). With Shorea robusta sawdust supplemented with gram flour, wheat bran, corn flour and rice bran, the colonization period of G. lucidum was 35 days in Nepal (Gurung et al., 2012).

\section{Effect of Sawdust Type on Days to Primordia Formation}

Rubber + Lunumidella (50\%:50\%) sawdust combination recorded the lowest number of days (32.9 d) for primordia formation (Table 2). However, it was not significantly different ( $p>0.05$ ) from 100\% Rubber, 100\% Mango or Rubber + Mango (50\%:50\%) sawdust types. The time taken for primordia formation in $100 \%$ Jack sawdust was 52.6 days and it was significantly longer $(\mathrm{p}<0.05)$ when compared to other treatments. Lunumidella (100\%) and Rubber + Jack (50\%:50\%) sawdust treatments took 40.9 days and 40.7 days, respectively which were not significantly different from each other.

When Rubber + Mango sawdust substrate was used in 75\%:25\% ratio, it took 65 days to appear the first primordium (Bandaranayake et al., 2012). However, in the current study with Rubber + Mango at 50\%:50\%, the time period was reduced to 34 days.

\section{Effect of Sawdust Type on Days to First Harvest}

The minimum number of days for the first harvest of fruiting bodies was taken by Rubber + Lunumidella (50\%:50\%) sawdust mixture (50.1 days; Table 2). However, it was not significantly different $(\mathrm{p}>0.05)$ from Rubber (100\%; 53.5 d), Mango (100\%; 51.7 d) and Rubber + Mango (50\%:50\%; 51.3 d) treatments. Jack sawdust (100\%) recorded a 

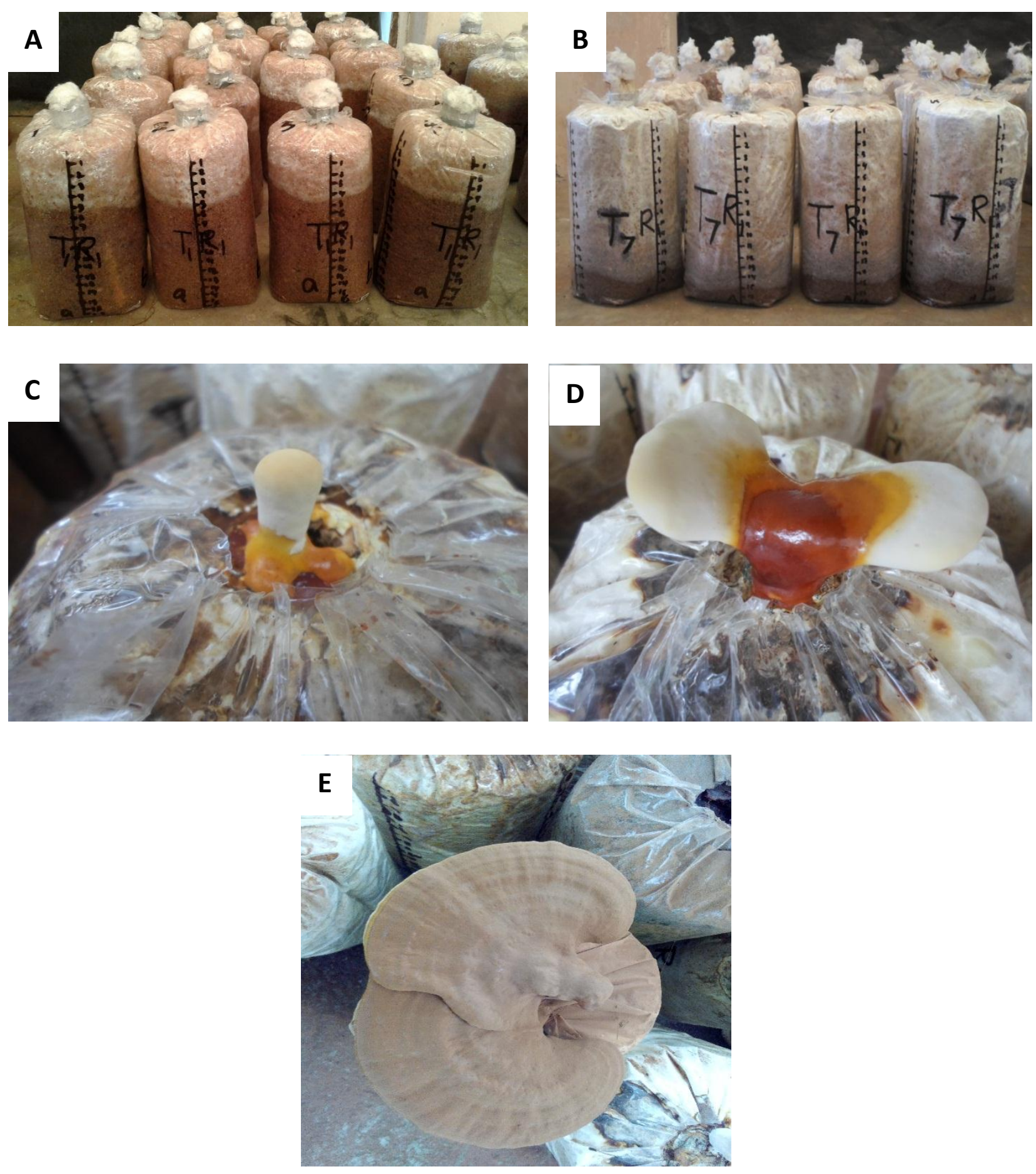

Figure 1. Growth stages of Ganoderma lucidum in grow bags. A) Early stage of mycelium growth (Spawn running), B) Completion of mycelium growth, C) Pin head formation, D) Early stages of fruiting body growth, E) Harvesting stage. 
Growth and Yield of Reishi Mushroom in Different Sawdust Substrates

Table 2. Effect of different sawdust substrates on the growth parameters of Ganoderma lucidum

\begin{tabular}{lcccccr}
\hline $\begin{array}{c}\text { Sawdust } \\
\text { type }\end{array}$ & $\begin{array}{c}\text { Colonization } \\
\text { period } \\
\text { (days) }\end{array}$ & $\begin{array}{c}\text { Days to } \\
\text { primordial } \\
\text { formation }\end{array}$ & $\begin{array}{c}\text { Days to } \\
\text { first } \\
\text { harvest }\end{array}$ & $\begin{array}{c}\text { Number of } \\
\text { fruiting } \\
\text { bodies per } \\
\text { bag }\end{array}$ & $\begin{array}{c}\text { *Yield per } \\
\text { bag } \\
(\mathbf{g})\end{array}$ & $\begin{array}{c}\text { Biological } \\
\text { Efficiency } \\
(\%)\end{array}$ \\
\hline Rubber & $25.4 \pm 0.40^{\mathrm{c}}$ & $35.8 \pm 0.50^{\mathrm{c}}$ & $53.5 \pm 0.53^{\mathrm{c}}$ & $3.7 \pm 0.24^{\mathrm{a}}$ & $42.5 \pm 4.35^{\mathrm{a}}$ & $5.1^{\mathrm{ab}}$ \\
Mango & $27.8 \pm 0.20^{\mathrm{b}}$ & $33.6 \pm 0.92^{\mathrm{c}}$ & $51.7 \pm 2.25^{\mathrm{c}}$ & $3.2 \pm 0.35^{\mathrm{ab}}$ & $49.3 \pm 5.74^{\mathrm{a}}$ & $5.4^{\mathrm{a}}$ \\
Jack & $34.2 \pm 0.70^{\mathrm{a}}$ & $52.6 \pm 0.70^{\mathrm{a}}$ & $75.3 \pm 2.03^{\mathrm{a}}$ & $2.2 \pm 0.15^{\mathrm{cd}}$ & $29.4 \pm 1.56^{\mathrm{b}}$ & $2.7^{\mathrm{bc}}$ \\
Lunumidella & $27.4 \pm 0.60^{\mathrm{b}}$ & $40.9 \pm 0.60^{\mathrm{b}}$ & $60.2 \pm 2.73^{\mathrm{b}}$ & $2.1 \pm 0.24^{\mathrm{d}}$ & $28.3 \pm 5.34^{\mathrm{b}}$ & $3.6^{\mathrm{bc}}$ \\
Rub: Mango & $27.6 \pm 0.20^{\mathrm{b}}$ & $34.1 \pm 0.20^{\mathrm{c}}$ & $51.3 \pm 0.48^{\mathrm{c}}$ & $2.7 \pm 0.13^{\mathrm{bc}}$ & $45.7 \pm 3.53^{\mathrm{a}}$ & $5.3^{\mathrm{a}}$ \\
Rub: Jack & $27.8 \pm 0.20^{\mathrm{b}}$ & $40.7 \pm 0.20^{\mathrm{b}}$ & $62.6 \pm 1.43^{\mathrm{b}}$ & $1.8 \pm 0.09^{\mathrm{d}}$ & $26.3 \pm 1.70^{\mathrm{b}}$ & $2.5^{\mathrm{bc}}$ \\
Rub: Lun & $25.6 \pm 0.35^{\mathrm{c}}$ & $32.9 \pm 0.24^{\mathrm{c}}$ & $50.1 \pm 1.03^{\mathrm{c}}$ & $3.3 \pm 0.07^{\mathrm{ab}}$ & $43.7 \pm 5.28^{\mathrm{a}}$ & $5.7^{\mathrm{a}}$ \\
\hline
\end{tabular}

Each value is the Mean \pm SE of three replicate analyses. Means with different superscript letters within a column are significantly different at $p<0.05$.

Sawdust mixtures - Rubber (Rub): Mango 50\%:50\%; Rubber: Jack 50\%:50\%; Rubber: Lunumidella (Lun) $50 \%: 50 \%$ ).

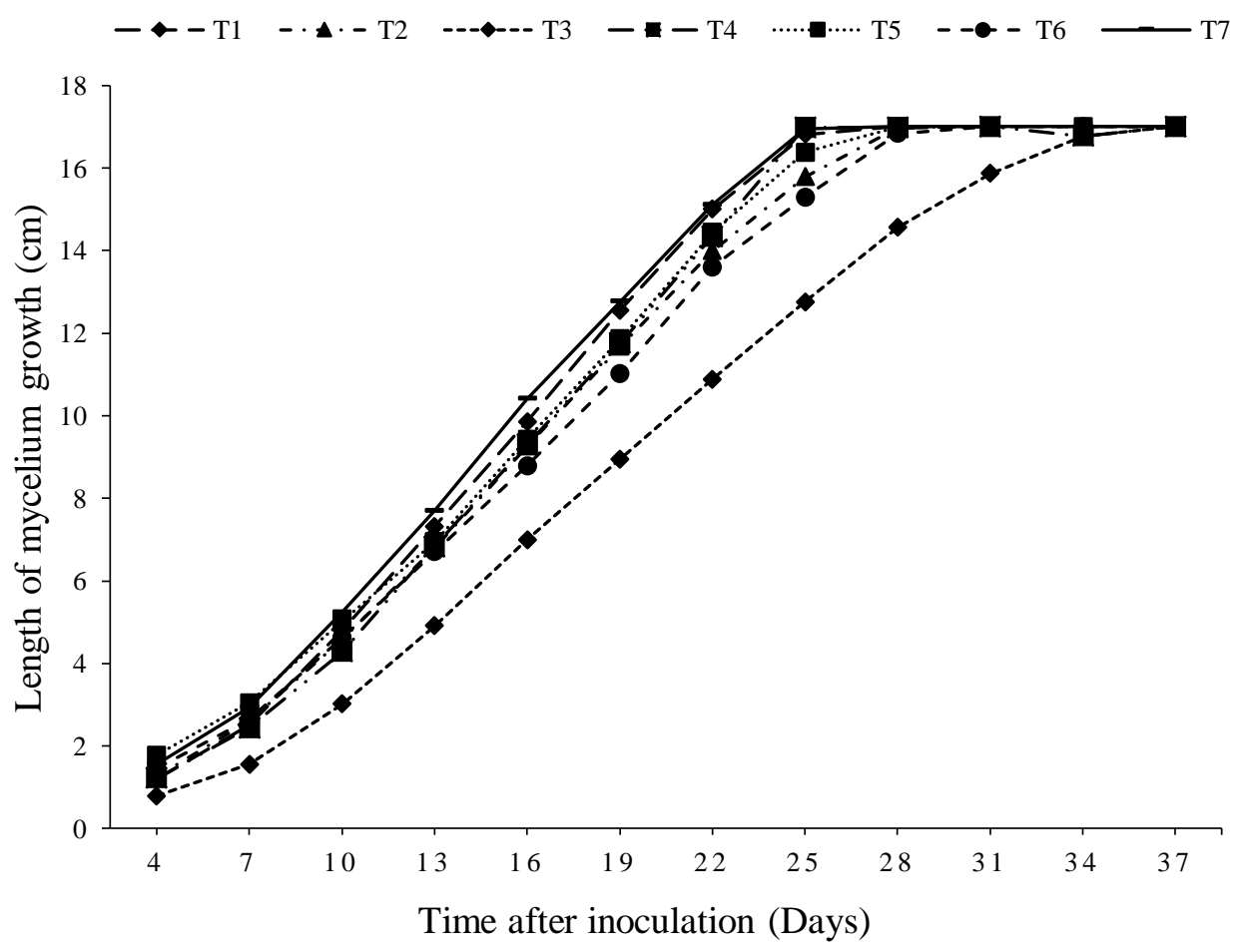

Figure 2. Mycelium growth rate of Ganoderma lucidum on different sawdust substrates T1- 100\% Rubber, T2- 100\% Mango, T3- 100\% Jack, T4- 100\% Lunumidella, T5- 50\% Rubber+50\% Mango, T6- 50\% Rubber+50\% Jack, T7- 50\% Rubber+50\% Lunumidella. 
relatively longer time for the first harvest (75.3 d; Table 2).

Rubber + Lunumidella (50\%:50\%), Rubber (100\%), Mango (100\%) and Rubber + Mango (50\%:50\%) sawdust treatments used in the present study showed lower days to first harvest of fruiting bodies when compared to the results $(60-90 \mathrm{~d})$ obtained with the Shorea mahagoni, Dipterocarpus turbinatus, S. robusta and Alnus nepalensis sawdust substrates (Gurung et al., 2012; Roy et al., 2015).

\section{Effect of Sawdust Type on Number of Fruiting Bodies per Bag}

The highest average number of fruiting bodies per bag was obtained from Rubber (100\%) sawdust (3.7) and it was significantly different $(\mathrm{p}<0.05)$ from Jack $(100 \%)$, Lunumidella (100\%), and Rubber + Mango (50\%:50\%) and Rubber + Jack (50\%:50\%) treatments which gave 2.2, 2.1, 2.7 and 1.8 fruiting bodies per bag, respectively (Table

\section{Yield and Biological Efficiency (\%)}

The highest average yield per bag within amonth after fruiting body initiation was obtained with Mango (100\%) sawdust (49.3 $\mathrm{g} / \mathrm{bag}$ ). However, it was not significantly different $(p>0.05)$ from the yield per bag of Rubber (42.5 g/bag), Rubber + Mango (50\%:50\%; $45.7 \mathrm{~g} / \mathrm{bag})$ or Rubber + Lunumidella (50\%:50\%; $43.7 \mathrm{~g} / \mathrm{bag})$ treatments. Jack (100\%), Lunumidella (100\%) and Rubber + Jack (50\%:50\%) sawdust resulted in low yields.

The predicted total yield per bag for a period of 3 months from fruiting body initiation is shown in Figure 3. The highest total yield was resulted by $100 \%$ Mango sawdust $(541.91 \mathrm{~g} / \mathrm{bag})$ followed by Rubber + Mango sawdust (502.37 g/bag), and Rubber + Lunumidella sawdust (480.92 g/bag) substrates which were not significantly different $(p>0.05)$ from each other. The minimum yield (289.08 g) was given by Rubber + Jack sawdust substrate. 2).

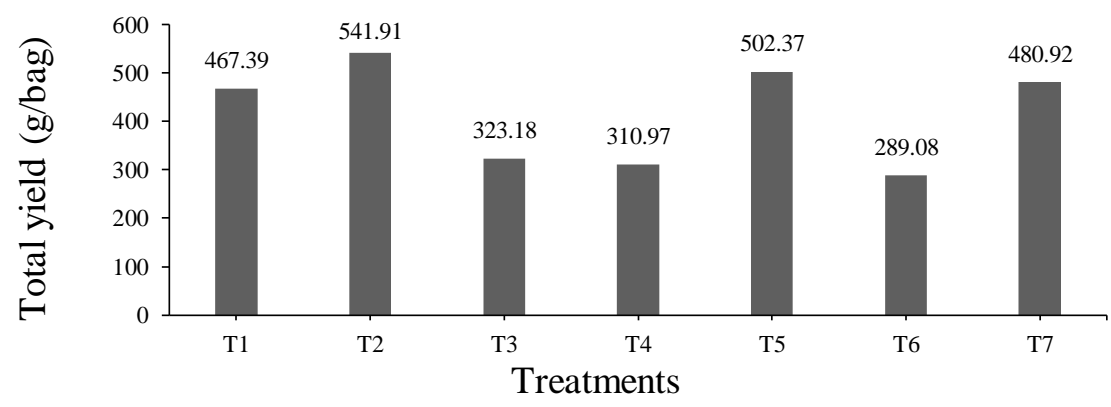

Figure 3. Predicted total yield of Ganoderma lucidum for three months from fruiting body initiation

T1- 100\% Rubber, T2- 100\% Mango, T3- 100\% Jack, T4- 100\% Lunumidella, T5- 50\% Rubber+50\% Mango, T6- 50\% Rubber+50\% Jack, T7- 50\% Rubber+50\% Lunumidella. 
The feasibility of substrates was determined by calculating the Biological Efficiency (BE \%). It indicates the maximum net return from each substrate used for mushroom cultivation and $\mathrm{BE}$ depends on the type of the substrate used (i.e. sawdust, leaves, cotton waste or paddy straw). The maximum BE $(5.7 \%)$ was achieved by the Rubber + Lunumidella (50\%:50\%) sawdust substrate. However, it was not significantly different ( $p>0.05$ ) from 100\% Rubber, 100\% Mango and Rubber + Mango (50\%:50\%) sawdust types. Both the lower yield and BE were recorded in Jack (100\%), Lunumidella (100\%) and Rubber + Jack (50\%:50\%) sawdust substrates (Table 2).

A study conducted in Bangladesh achieved a yield of $235.2 \mathrm{~g} / \mathrm{bag}$ with $\mathrm{BE}$ of $7.6 \%$ for S. mahogani and yield of 210.9 g/bag with BE of $6.8 \%$ for Dipterocarpus turbinatus sawdust supplemented with wheat bran (Roy et al., 2015). A previous study in Sri Lanka reported a maximum yield of 131 $\mathrm{g} / \mathrm{bag}$ in $100 \%$ Rubber sawdust compared to other treatment combinations where the $\mathrm{BE}$ has not been measured (Bandaranayake et al., 2012). The predicted total yield in the current study was, however, higher than the values reported in previous study.

The commonly used substrate in mushroom culture, i.e. rubber saw dust (100\%), gave a higher yield with higher Biological Efficiency (BE) for G. lucidum. Nevertheless, Mango (100\%), Rubber + Mango (50\%:50\%) and Rubber +
Lunumidella (50\%:50\%) sawdust substrates too resulted in higher yields and higher BE. Sawdust of jack, alone or in mixture, and Lunumidella alone cannot be recommended as growing media, as they resulted in lower yields and low BE.

\section{CONCLUSION}

The effect of various wood sawdust substrates on the yield of G. lucidum was investigated in this study. Considering the scarcity of rubber and mango wood as a sole source for substrate, the mixture of rubber and mango (50\%:50\%) or rubber and Lunumidella (50\%:50\%) could be recommended for cultivation of G. lucidum. Further research is recommended with the addition of nutrient supplements to the growing medium.

\section{ACKNOWLEDGEMENT}

The authors gratefully acknowledge $\mathrm{Mr}$. K.H.M.I. Karunarathne, Lecturer, Wayamba University of Sri Lanka, for his assistance in statistical analysis. Support provided by the staff of the RARDC, Makandura, is appreciated.

\section{REFERENCES}

Bandaranayake, E.M.L.O.K., Rajapakse, P. and Weerakkody, N.S. (2012). Selection of suitable sawdust as growing media for Reishi mushroom (Ganoderma lucidum) cultivation. In Proceedings of the Annual Academic Sessions, Open University of 
Sri Lanka, 21-24.

Chang, S.T. and Miles, P.G. (1997). Mushroom Biology, World Scientific Publishing Co. Pte. Ltd, Singapore.

Chang, S.T. and Buswell, J.A. (1999). Ganoderma lucidum (Curt:Fr.) P. Karst. (Aphyllophoromycetideae):

A mushrooming medicinal mushroom. International Journal of Medicinal Mushrooms, 1: 139-146.

Chang, S.T. and Miles, P.G. (2004). Mushrooms: Cultivation, Nutritional Value, Medicinal Effect and Environmental Impact. $2^{\text {nd }}$ Edition, CRC Press LLC, Florida.

Gurung, O.K., Budathoki, U. and Parajuli, G. (2012). Effect of different substrates on the production of Ganoderma lucidum (Curt: Fr) Karst. Our Nature, 10: 191198.

Hsieh, C. and Yang, F. (2004). Reusing soy residue for the solid-state fermentation of Ganoderma lucidum. Bioresource Technology, 91:105-110.

Roy, S., Jahan, M.A.A., Das, K.K., Munshi, S.K. and Noor, R. (2015). Artificial cultivation of Ganoderma lucidum (Reishi medicinal mushroom) using different sawdust substrates. American Journal of Bioscience, 3: 178- 182.

Wachtel-Galor, S., Yuen, J., Buswell, J.A. and Benzie, I.F.F. (2011). Herbal Medicine: Biomolecular and Clinical Aspects. $2^{\text {nd }}$ Edition, CRC Press, Florida.

Wasser, S.P., Coates, P., Blackman, M., Cragg, G., Levine, M., Moss, J. and White, J. (2005). Reishi or Lingzhi
(Ganoderma lucidum). Encyclopaedia of Dietary Supplements. Marcel Dekker, New York. 680-690. 